See discussions, stats, and author profiles for this publication at: https://www.researchgate.net/publication/346620640

\title{
Legitimating falsehood in social media: A discourse analysis of political fake news
}

Article in Discourse \& Communication · November 2020

DOI: 10.1177/1750481320961659

CITATION

1

2 authors:

Ebuka Igwebuike

Christian-Albrechts-Universität zu Kiel

26 PUBLICATIONS 13 CITATIONS

SEE PROFILE
READS

50

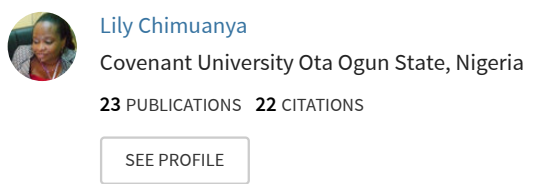

Some of the authors of this publication are also working on these related projects:

A Study of Stylistic Features of Selected Nigerian Pentecostal Texts on Facebook and Twitter View project

Investigation of the Compressive, Split Tensile and Flexural Characteristics of Steel Scrap Composite Concrete View project 


\title{
Legitimating Falsehood in Social Media: A Discourse Analysis of Political Fake News
}

\author{
Ebuka Elias Igwebuike \\ International Political Sociology, the Christian-Albrecht University of Kiel, Germany \\ Department of English and Literary Studies, Alex Ekwueme Federal University, Ikwo, Nigeria \\ igwebuike@ips.uni-kiel.de ebukaigwebuike@yahoo.com
}

\author{
$\underline{\&}$ \\ Lily Chimuanya \\ Department of Languages and General Studies \\ Covenant University, Ota, Nigeria \\ lily.chimuanya@.covenantuniversity.edu.ng
}

Note: This is the accepted copy of this paper. The final and definitive copy has been published in Discourse \& Communication by SAGE Publications Ltd

To cite this article: Igwebuike, E. E. \& Chimuanya, L. (2021). 'Legitimating Falsehood in Social Media: A Discourse Analysis of Political Fake News'. In: Discourse \& Communication. Sage Publications. Vol. 15, No.1, pp. 42-58.

To link to this article: https://doi.org/10.1177/1750481320961659

\begin{abstract}
Digital peddling of fake news is influential to persuasive political participation, with veritable social media platforms. Social media, with their instantaneous and widespread usage, have been exploited by 'anonymous' political influencers who fabricate and inundate internet community with unverified and false information. Using van Leeuwen's Discourse Legitimation approach and insights from Discourse Analysis, this study analyses 120 purposively sampled fake news posts on Whatsapp, Facebook and Twitter, shared during the 2019 general elections in Nigeria. WhatsApp allows for the easy and fast sharing of fake news as it pulled the largest occurrence of legitimation strategies, followed by Facebook. Authorisation is the highest occurring legitimation strategy at $46.6 \%$ frequency; this is followed by Moralisation which has $27 \%$ and Rationalisation at 26.4\%; while Mythopoesis did not feature at all in the sampled data, leaving it at $0 \%$. In particular, expert and role model authority are most often deployed to validate fake news such as the demise and cloning of President Buhari, ruling party's plan to rig and destabilise the 2019
\end{abstract}


election, massive corruption in the current administration and imminent ethnic violence. The study argues that these strategies are viable persuasive tools owing to their use of discourse markers like make-believe images, emotive language, appeal to emotions, rational conclusions, hateful comments, verbal indictment and coercive verbs.

Key words: Fake news, legitimation strategies, discourse analysis, social media, Nigerian election

\section{Introduction}

In Nigeria, the social media have dramatically changed political discussions and political participations with their instantaneous and widespread campaign information and disinformation. According to the social media poll report (2019), about 120 million Nigerians (61\%) have access to the internet while findings reveal that the proportion of people using each social networking platform includes -Facebook ( 86 percent), WhatsApp (84 percent), Instagram (19 percent), Twitter (11 percent), and Snapchat (2 percent) (NOIPolls, 2019). Out of these, about 19\% and $8 \%$ of Twitter and WhatsApp users respectively spend upwards of 10 hours daily on the average on the social media sites, making social media vital tools in the hands of political influencers for providing information to the public on political events, engaging their users, and encouraging them to get involved in online and offline political activities (Ahmad, Alvi and Ittefaq, 2019). Most notably, political influencers and manipulators have embraced social media in disseminating political information (Stieglitz and Dang-Xuan, 2014) as well as disinformation to manipulate public opinion (Ahmad, Alvi and Ittefaq, 2019).

Peddling of fake news relies on a wealth of platforms, such as digital media and social networks. Fake news has witnessed tremendous increase with the development of social networking sites with statistics showing that $43 \%$ of social media users get their news from Facebook, 500 million people use Instagram story everyday with over 1 billion monthly active users, while as at the first quarter of 2019, Twitter had 330 million active users and 134 million daily active users and 500 million tweets sent out each day (https://www.socialpilot.co/blog/socialmedia-statistics). The implication of the massive use of social media, especially for disseminating fabricated information and propaganda during electoral processes is that it affects responses and behaviours of potential voters as well as threatens democratic processes (Prasetyo and Asiyah, 2017). A recent study reveals that fake news had powerful effect and influence in the 2016 
American pre and post-election periods, which further aggravated the entire electoral process and almost leading up to an eruption (van Duyn and Collier, 2019). More fake news stories were shared during the election period than authentic stories with more people believing the fake reports (Silverman, 2016; Albright, 2017). Social media platforms such as Facebook and Twitter served as major platforms for sharing increased number of fabricated information, propaganda and deceptive content during the election (Silverman, 2016; Vosoughi, Roy and Aral, 2018; Bovet and Makse, 2019).

In Nigeria, the facility of text messaging heralded the emergence of viral fake news. The Ebola-salt solution text messages that subtly demanded citizens to bathe in and drink warn salt water to avoid contracting the deadly Ebola virus in 2014 was probably the first most widespread fake news (Chimuanya and Ajiboye 2016; Nababa, 2016). Consequently, two people died and 20 were hospitalized for excessive consumption of salt water (Okafor, 2018). Since the Ebola fake news in 2014, the over 120 million internet subscribers have continued to receive similar unsolicited fake information on social networking sites with a significant climax during the 2019 general election. Fabricated stories of the death and cloning of President Buhari who was seeking reelection in the 2019 election were massively circulated on different platforms to discredit the president (Parkinson, 2018). Uncomplimentary diverse reactions generated by the news including damaging political outcomes forced the president to debunk the rumour at a news conference in Poland by stating 'It's the real me' (The Guardian, Dec. 3, 2018).

This study focuses on examining peddled fake news on social media platforms. It aims at exploring the legitimation strategies that are deployed to validate false information on WhatsApp, Facebook and Twitter during the 2019 general elections in Nigeria. Specifically, the study seeks to identify and categorise the legitimation strategies used on the different platforms; examine and analyse linguistic features in the fake news and discuss the socio-political implications of the identified legitimation and linguistic features.

\section{Review of Literature}

\section{Fake News, Social Media and Politics}


The term "fake news" was popularized by Donald Trump during his presidential campaign to designate news that critiqued his political positions and interests (Chiluwa and Samoilenko, 2019). Fake news has been variously defined, with most of the definitions revolving around its motivations for misinformation, disinformation propaganda, and stimulus for distribution, which includee financial and ideological inducement. Allcott and Gentzkow (2017:213) see it as "news articles that are intentionally and verifiably false, and could mislead readers." However, like Allcott and Gentzkow, Lazer et al, (2018:1094) have noted that fake news includes "fabricated information that mimics news media content in form but not in organizational process or intent." Wardle (2017) agrees to these definitions when he submits that fake news is an instance of misinformation. These definitions foreground two major attributes of fake news; false information that pretends to be real news. This portends that not all false reports are fake news but only deliberate information masquerading as true are. Difficulty is thereby created on identifying intentional fabrications in the age of infodemic. According to Tandoc, et al, (2018), differentiating a fake news from an authentic news is challenging in the present age as fake news is different from news parodies, political satire and news propaganda even though they are all related on the ground of intention to mislead. Tandoc, et al, (2018) provide an insight that the objectives of fake news are achieved only when audience mistake fake news as real news and the news influences them to like or share the content. The number of 'likes' on a fake news article on social media also serves as basis for its effect on the audience.

Studies in fake news in Nigeria cut across examining the challenges in curtailing the spread of fake news on social media (Assay, 2019); misinformation and deception in business communication (Chiluwa et al, 2019); and deception and fake news in political advertising (Aririguzoh, 2019). The steady growth, spread and potential damaging effects of fake news, especially in contributing to heightened ethno-political and religious tensions in the country have brought about the launching of 'CrossCheck Nigeria' (https://crosschecknigeria.org/), a collaborative verification project aimed at investigating the accuracy of report and helping the public to sort out misleading and false information. Although CrossCheck Nigeria as well as Africa Check has persuaded both mainstream media and owners of social media sites to verify information before it is published or shared, fake news continues to be distributed. Misinformation spreads when the many likes against a fake post and retweets/shares make it appear credible 
(Amobi, 2019). Fake news, therefore, comprises fabricated information geared towards legitimating falsehood to achieve political gains.

Social media have affected the way and manner fake news is distributed. They have added viable tools for misinformation and manipulation, especially the interactive tools that enable inexpensive new releases and fast re-publication of information (Abdulrauf, 2016). The developments in online information platforms have provided space for non-journalists to produce news including misinformation and reach a mass audience (Robinson and Deshano, 2011). Unlike in the traditional censored media outlets, fake news travels faster, farther and deeper in the digitalized media (Vosoughi, Roy and Aral 2018). With the developments in online information platforms, social media have become the main source of news for a growing number of individuals. Over 60 percentage of the 120 million internet users in Nigeria receive their news on social media (Olabamiji, 2014). Proliferation of misinformation is enhanced by the tendency of people to follow those who share their belief and accept news shared collectively in groups or by a person in authority. Thus, when people are presented with claims whose veracity is ambiguous they are less likely to fact-check the claims when the information is consumed in a group setting (Jun, Meng, and Johar 2017). Fake news on social media has remained a misleading and deceptive persuasive tool influencing people and institutions, especially political activities across the globe (Silverman, 2016).

The advent of social media has revolutionised political activities as social media platforms have provided online users the opportunities to discuss politics and participate in politics offline (Ahmad, Alvi and Ittefaq, 2019). Digitalised political interactions have yielded new media concepts such as netizen, cyber-democracy, e-governance, e-participation, etc. The Internet technology in general affords the possibility for a democratic postmodern public sphere where citizens can participate in well informed, non-hierarchical deliberations on issues affecting their social structures (Kellner and Bohman, 2013). According to Abdulrauf (2016), access to political information on Facebook and Twitter has increased political knowledge and political participation among the youth in Nigeria and Malaysia. Many political parties have Facebook pages they use for citizen engagement and opinion polls (Stieglitz and Dang-Xuan, 2014). In addition to virtual political campaigns for seeking supports, political parties discredit political opponents using unconfirmed news and propaganda shared through social media. WhatsApp, Facebook and Twitter 
served as instant podiums for spontaneity and wide distribution of friendly and damaging speculative political messages. Such news often has an effect on the outcome of elections (Uzochukwu and Ekwugha, 2014) and also on the political stability and democratic outcomes of any nation (Allcott and Gentzkow, 2017). This study aims at examining discursive strategies used to justify falsehood in selected fake news items sampled from WhatsApp, Facebook and Twitter during the 2019 Nigerian general elections.

\section{Theoretical Framework: van Leeuwen Discourse Model of Legitimation}

The theoretical framework used in this study is van Leeuwen's discourse model of legitimation, which identifies and examines different means to which social practices are justified. van Leeuwen (2007, 2008) presents a comprehensive analytical framework comprising authorisation, rationalisation, moralisation and mythopoesis for the analysis of discursive and linguistic use of legitimation in discourse. These strategies, according to van Leeuwen (2007) can be used for both legitimation and delegitimation and can also be used separately or in combination depending on the aims the speaker/writer wants to achieve. While legitimation means the creation of a sense of positive, beneficial or ethical justifications to make an action or view acceptable, delegitimation is a means of establishing a negative, unethical or immoral justification to make a view or an action unacceptable (Rojo and van Dijk, 1997; van Dijk, 1998; van Leeuwen and Wodak, 1999).

Authorisation is achieved by making reference to authority of tradition, custom and law, and of person or public figures (such as government or politicians) in whom some kind of institutional authority has been bestowed (van Leeuwen, 2007). To van Leuuwen, this strategy involves legitimation of behaviour by referring to esteemed or established authority such as personal, impersonal, expert, role model, traditional and conformity. Rationalisation is based on the shared assumption of what is considered right and rational. It involves referring to knowledge, claims, logic, and arguments or to goals in order to validate a social action as beneficial or rational. Rationalisation is subdivided into theoretical and instrumental. While the former relies on explanation, definition and prediction, the latter focusses on references to means, goals and effects of actions

Moralisation is legitimation realised by making explicit or implicit reference to specific norms or moral value (or ethical) systems using evaluation, abstraction or analogy. These are used 
to offer moral and ideological basis for specific actions, which is about what is right and what is wrong. While evaluation is hinged on the use of evaluative adjectives such as normal and natural to judge actions as good or bad, abstraction relies on linking abstract practices to discourses with the aim of moralising and legitimating them. Analogy, on its own, entails explicit or implicit comparison of social actions as positive or negative. Mythopoesis is legitimation achieved through narratives or short stories whose outcomes show a reward for good actions and punishment for bad actions. The narratives, which can be moral or cautionary tales, are used to concretize and judge past or future actions. While moral tales depends on stories to approve or endorse legitimate actions, cautionary tales emphasise negative consequences that will follow non-legitimate actions. van Leeuwen's discourse model of legitimation would provide useful insights on strategic manipulation and deployment of discursive strategies in fake news to achieve political gains.

\section{Methodological Details}

The study uses both qualitative and quantitative approaches. Out of six hundred and eighty-six fake posts verified by CrossCheck Nigeria, one hundred and twenty fake news posts were sampled from three main Nigerian social media platforms, comprising 40 each from WhatsApp, Facebook and Twitter. It is important to state that some of the fake posts were shared across the platforms while some featured in either one or two of them. The fake news posts were purposively selected based on their political thematic preoccupation and the number of likes and shares they generated. This means that only posts which centre on Nigerian politics were selected. The posts were collected over a period of one year, that is, from June 2018 to June 2019. This is the period that marks heightened activities on the 2019 general elections and many fake news were shared for legitimating and delegitimating political candidates and parties. The posts were thereafter categorised based on their sources and thematic preoccupations. A content analysis of the legitimation (linguistic) features was done to classify the posts according to their specific strategies. This is followed by a qualitative analysis of the form and functions of each of the strategies therein. It is important to point out that all the data on fake news for the analysis are crosschecked for their authenticity and unreliability. CrossCheck Nigeria provides the platform for checking inaccuracies of news and confirming fake news in Nigeria. CrossCheck Nigeria investigates news and refutes misinformation as either 'Fake', 'False' or 'Incorrect'. For instance, a fake news post that the FG plans to ban Instagram in Nigeria because it fuels laziness among the 
youth attributed to President Buhari shared widely on Facebook and Twitter was refuted by CrossCheck Nigeria on their website

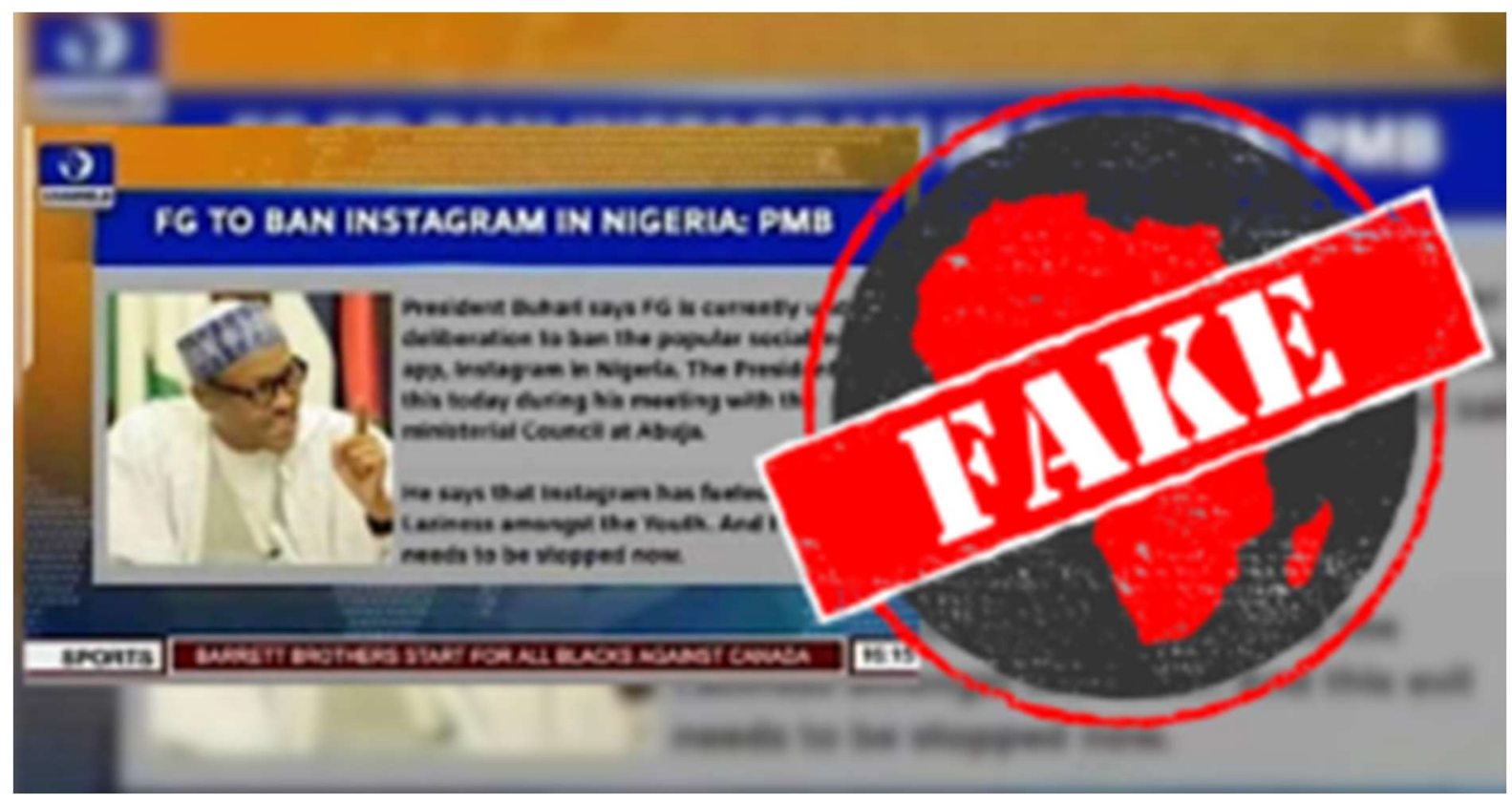

Figure 1: CrossCheck Nigeria

Both legitimation theory and discourse analysis are used in the analysis to examine instances of discursive strategies in validating misinformation in social media during the Nigerian 2019 general elections. Selected samples of data obtained, identified with 'FP' (representing 'Fake Post post') are reproduced within the analysis to reinforce discussions. The sources of data samples are also indicated in parentheses after the samples reproduced within analysis - TW for Twitter, FB for Facebook and WA for WhatsApp.

\section{Data Presentation and Analysis}

\begin{tabular}{|l|l|l|l|l|l|}
\hline Columns & \multirow{2}{*}{$\begin{array}{l}\text { Legitimation } \\
\text { Strategies }\end{array}$} & \multicolumn{4}{|c|}{ MEDIA } \\
\cline { 3 - 6 } & Facebook & Twitter & WhatsApp & Total \\
\hline A & Authorisation & & & & \\
\hline $\mathbf{1 .}$ & Personal & 6 & 4 & 8 & 18 \\
\hline $\mathbf{2 .}$ & Impersonal & 3 & 1 & 4 & 8 \\
\hline
\end{tabular}




\begin{tabular}{|c|c|c|c|c|c|}
\hline 3. & Expert & 14 & 6 & 16 & 36 \\
\hline 4. & Role model & 6 & 3 & 5 & 14 \\
\hline 5. & Tradition & 0 & 0 & 0 & 0 \\
\hline 6. & Conformity & 0 & 0 & 0 & 0 \\
\hline \multicolumn{2}{|c|}{ TOTAL } & 29 & 14 & 33 & 76 \\
\hline B & Moralisation & & & & \\
\hline 7 & Evaluation & 4 & 0 & 6 & 10 \\
\hline 8. & Abstraction & 6 & 1 & 4 & 11 \\
\hline 9. & Analogies & 10 & 1 & 12 & 23 \\
\hline \multicolumn{2}{|c|}{ TOTAL } & 20 & 2 & 22 & 44 \\
\hline C1 & $\begin{array}{l}\text { Rationalisation: } \\
\text { Instrumental }\end{array}$ & & & & \\
\hline 10. & Goal orientation & 0 & 0 & 0 & 0 \\
\hline 11. & $\begin{array}{l}\text { Means } \\
\text { orientation }\end{array}$ & 4 & 0 & 6 & 10 \\
\hline 12. & Effect orientation & 8 & 1 & 8 & 17 \\
\hline \multicolumn{2}{|c|}{ TOTAL } & 12 & 1 & 14 & 27 \\
\hline $\mathrm{C2}$ & $\begin{array}{l}\text { Rationalisation: } \\
\text { Theoretical }\end{array}$ & & & & \\
\hline 13. & Definition & 7 & 3 & 6 & 16 \\
\hline 14. & Explanation & 0 & 0 & 0 & 0 \\
\hline 15. & Prediction & 0 & 0 & 0 & 0 \\
\hline \multicolumn{2}{|c|}{ TOTAL } & 7 & 3 & 6 & 16 \\
\hline D & Mythopoesis & & & & \\
\hline 16. & Moral tales & 0 & 0 & 0 & 0 \\
\hline 17. & Cautionary tales & 0 & 0 & 0 & 0 \\
\hline 18. & $\begin{array}{l}\text { Single } \\
\text { determination }\end{array}$ & 0 & 0 & 0 & 0 \\
\hline 19. & Inversion & 0 & 0 & 0 & 0 \\
\hline 20. & Symbolisation & 0 & 0 & 0 & 0 \\
\hline
\end{tabular}




\begin{tabular}{|l|l|l|l|l|}
\hline \multicolumn{1}{|c|}{ TOTAL } & 0 & 0 & 0 & 0 \\
\hline $\begin{array}{l}\text { OVERALL } \\
\text { OCCURRENCE }\end{array}$ & 68 & 20 & 75 & 163 \\
\hline
\end{tabular}

Table 1: Frequency of Legitimation Strategies in the Social Media

Table 1 presents the number of realisations of legitimation strategies in specific social media. WhatsApp has the highest number of legitimation strategies, occurring 75 times. It is the easiest to use of all modes in terms of technicality, coupled with the fact that it incorporates all other social functions like personal and group interactions, bulk forwarding of messages and news, photo and video share, voice and video call (Yomi Kazeem, 2019). The next is Facebook (FB) with 68 legitimation strategies. Although FB now tries to implement some form of Fake news policies, users are still, to a large extent, at liberty to post their thoughts on their timelines with settings that allows such thoughts to be shared by viewers. Twitter has the least number of strategies with just 20 , most of which comes from authorisation and the least from mythopoesis; zero. Twitter allows for short tweets which, most of the times, are characterised by individual or group hashtags. It is also significant to point out that authorisation strategy and mythopoesis strategy also contribute the highest and lowest occurrences on both WhatsApp and Facebook. In other words, the most frequent legitimation strategy used by Nigerians on social media is authorisation with the highest forms being expert authority, characterised by the mention of a knowledgeable person in the subject matter of discourse as backup for the news. Role model authority is the second highest occurring strategy. The implication of this is that name tags on news items has the potency of making the content believable. The least used strategy is mythopoesis which is non-existent in our data sample. This legitimation strategy appears not to be a popular style among fake news creators.

Table 2: Categories of Legitimisation Strategies

\begin{tabular}{|l|l|l|}
\hline $\begin{array}{l}\text { Discursive } \\
\text { Strategies }\end{array}$ & $\begin{array}{l}\text { Token } \\
\text { Frequency }\end{array}$ & $\begin{array}{l}\text { Percentage } \\
\%\end{array}$ \\
\hline Authorisation & 76 & 46.6 \\
\hline Moralisation & 44 & 27 \\
\hline
\end{tabular}




\begin{tabular}{|l|l|l|}
\hline Rationalisation & 43 & 26.4 \\
\hline Mythopoesis & 0 & 0 \\
\hline Total & $\mathbf{1 6 3}$ & $\mathbf{1 0 0}$ \\
\hline
\end{tabular}

Table 2 shows the recurrent legitimisation strategies observed across the sample data. The highest occurring strategy is authorisation with $46.6 \%$. This is as a result of the urgency for fake news creators to back up false claim with expert backing in order to make it more believable and acceptable. A major grapevine catchphrase in Nigeria is 'they said', 'they' in that context referring to the authority or the miscellaneous entity bequeathed with the power to make pronouncements. Therefore, in print, fake news are often heralded with either the name of a person in authority, a reputable organisation or other identifiable authoritative sources. Moralisation strategy has a percentage frequency of $27 \%$, making it the second highest occurring strategy. Nigeria is notable for her oral tradition, a system that allows values and tradition to be passed down generations. This culture has also been used by fake news manufacturers as a convincing tool to captivate their victims. Very close to moralisation is rationalisation which has a $26.4 \%$ occurrence and manifests as narratives used to justify a claim. The most frequently use rationalisation strategy is instrumental rationalisation. The least occurring strategy is mythoeposis which did not occur at all and therefore has $0 \%$ frequency. Most Nigerian-based fake news are not always supported by logic or verifiable knowledge base because rather than the manufacturer waste time on researching the authenticity of a news story, they would rather resort to an easy and fast method of justifying their claim; such as expert or role model authority. This observation has implication for the knowledge orientation of Nigerians. Nigeria is a religious (moral) economy than a knowledge economy, hence the low reliance on logical argument and credible reference to support fake news.

The following discussion attempts to situate van Leewen's broad categorisation into the Nigerian situation in order to highlight the distinctive features that surround the use of each strategy.

\section{Legitimation by Authorisation}

As revealed in the Table 1, this is the most commonly used strategy. References are made to authorities to give authenticity, credibility as well as force to fake news items. News is considered reliable when it comes from instituted authorities. In the data, references are made to personal authority, expert authority and role model authority to justify false information. Authorisation goes 
with power in order to enhance credibility. People in power are taken as personal authorities to legitimate false claims that the ruling party (APC) plans violence against the electorate in the 2019 election. In FP 1, Reno Omokri, former aide to the ex-president Goodluck Johnathan, reconstructs the news about President Buhari's instruction to the army to deal with (that is, apprehend) election thugs and ballot-box snatchers to include the use of brutal force in his viral tweet. He employs the voice of the Army spokesperson, Colonel Sagir Musa, as personal authority to misinform online user that the army is prepared to 'shoot' electoral offenders as commanded by the president. Misinformation is inherent in the assertion 'shooting of ballot box snatchers' instead of the accurate information that the army plans to deploy personnel for the elections, but only on contingent bases on the outer perimeter of communities rather than near polling units. This fake information invariably created fears in some electorates who would have planned to vote in the election.

FP 1: 'If the Commander-in-Chief has given order to the @HQNigerianArmy to that effect (shooting of ballot box snatchers, be rest assured that order will be totally and effectively obeyed without any ifs and buts' - Nigerian Army Spokesman Colonel Sagir Musa (TW: @renoomokri; 10: 51PM; 18 February, 2019)

FP 2: BREAKING NEWS !!! Brigadier General Sani Kukasheka Usman, Director Army Public Relations, Announces His Voluntary Retirement From The Nigerian Army. Saying!! I will not be part of what The presidency planned against innocent Nigerian if Buhari didn't win 2019 Election!!! (FB: Dailymail Gist and Naija Must Work Again; 12: 15AM, 19 February, 2019)

In the same vein, FP 2 uses Brigadier General Sani Kukasheka as a personal authority to legitimate false claims that the president secretly plans to be ruthless to voters if he loses the 2019 election. This particular fake news erroneously builds on the retirement message of the immediate past Army spokesperson who had served the army for 35 years. The verbal process in the second paragraph attributes the voluntary retirement of the spokesperson to planned secret violence by the presidency if he loses the election. The statement is hinged on previous statement of the president that if the 2015 election is rigged as it was in the 2011 election, then 'the dog and the baboon would all be soaked in blood.' The post therefore uses the voice of the army spokesperson to legitimate the false information and by extension, instils fear and subtle hatred in the Nigerian electorates who are described as the innocent. The electorate are presented the option to re-elect 
the president to be safe or vote him out and face the 'planned attack'. The photo of Brigadier General Sani Kukasheka is included in the news post to further authenticate the fake news.

Unlike in the previous examples where the ruling party is delegitimated, some fake posts use people with some authority to offer justification that the ruling party is better than the opposition. Here, the voices of presidents and ministers are deployed. For example:

FP 3: 'BREAKING. Democracy under Buhari is one of the best in the world' German Chancellor Angela Merkel (TW: @trueNija; 9: 23PM; 3 February 2019)

FP 4: PDP used Osinbajo's helicopter for 16 years without servicing it' Lai Mohammed, the Minister of Information'. (TW: @SweetShantel; 2:14 PM; 3 February 2019)

FP 5:"We Saw A PDP Membership Card And Atiku Abubakar's Bank Cheque In The Pocket Of The Pilot That Crashed Our Osinbajo's Helicopter" Lai Mohammed, the Minister

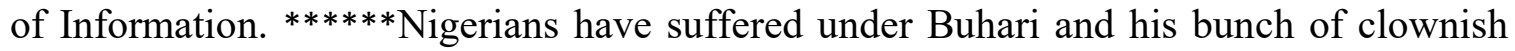
Ministers. What is Lai Mohammed Smoking? (FB: Hope for Nigeria; 12: 38 PM; 3 February, 2019)

In the samples above, the President, Chancellor and minister are used as expert authorities. FP 3 and FP 4 use the voices of Angela Merkel, the German Chancellor and Nigerian Minister of Information to legitimate the claim that the present administration is better than the past administration. While FP 3 attempts to legitimate false claim that Buhari's administration practices one of best democracies in the world, FB 4 makes reference to PDP as a party that crashed the Vice President's helicopter, hence; the party is the cause of the accident in which the Vice President narrowly survived. The use of the pronoun 'We' in FP 5 suggests that the Minister did not act alone but in company of other unnamed investigators, the inclusiveness portrayed further gives credence to FP 5.

Authorisation by expert authority occurs by making reference to something said or written by an expert in a particular field. In the data, institutions such as reputable media houses (e.g. Channels TV, CNN) and organisations such as World Health Organisations, Manufacturers Association of Nigeria, and other reputed institutions are used as experts who are knowledgeable in their specific fields for legitimation. Examples are shown in FP6 to FP8 below:

FP 6: Breaking New! CNN have finally released the news of the demise of Buhari which took place January 27 2017. This is the highest fraudulent act that have ever committed in 
the land by northen cabals and they should all be arrested now. (FB: Biafra News; 9: 26PM; 15 November 15, 2018)

FP 7: The Manufacturers Association of Nigeria reveals that 800 firms folded up in 3 years due to President @MBuhari's failed government, yet the President, with all his 'integrity', went to NASS yesterday to boast of 'economic recovery' \#Buhari2019BudgetLies (TW. @renoomokri Twitter, 17: 54PM, 20 December, 2018)

FP 8: Breaking: WHO warns Southern Nigerians of cattle plague, asks them to stop eating cows from the north. The World Health Organisation has warned people in the south of Nigeria to stop eating meat from cows reared by the Fulani community in the north. The WHO's director-general Tedros Adhanom this was due to a "cattle plague... culpable of killing citizens". The "plague' was caused on purpose with a political motive. "According to him, the cow meat have all been infested by the Fulanis with the intention to wipe out the Southerners, more especially, the Yorubas and Igbos with the cow diseases before 2028." (WA: Rescue Mandate; .....)

While FP 6 uses CNN, FP 7 uses Manufacturers Association of Nigerian (MAN) as expert authority to legitimate falsehood. FP 6 is one fake news that generated a lot of concerns and reactions from Nigerians. It started with Maazi (Mr.) Nnamdi Kanu, the secessionist leader of the Indigenous Peoples of Biafra's allegations that the president died in one of his medical trips to London and was replaced with a look-alike from Sudan. The post builds on that allegation with a report that the CNN has 'finally release the news of the demise of Buhari which took January 27 2017' (SIC). Reference is made to CNN, a renowned news agency, to substantiate this claim as it has 'finally' released its own version of the news. CNN is one of the most trusted media outfit in terms of relaying 'authentic' news. Thus, the use of make-believe photo where the supposedly corpse of the president is covered in white cloth and the use of CNN logo with the inscription 'BREAKING NEWS/WORLD NEWS' add to giving false credibility to the news as shown in the picture below. 


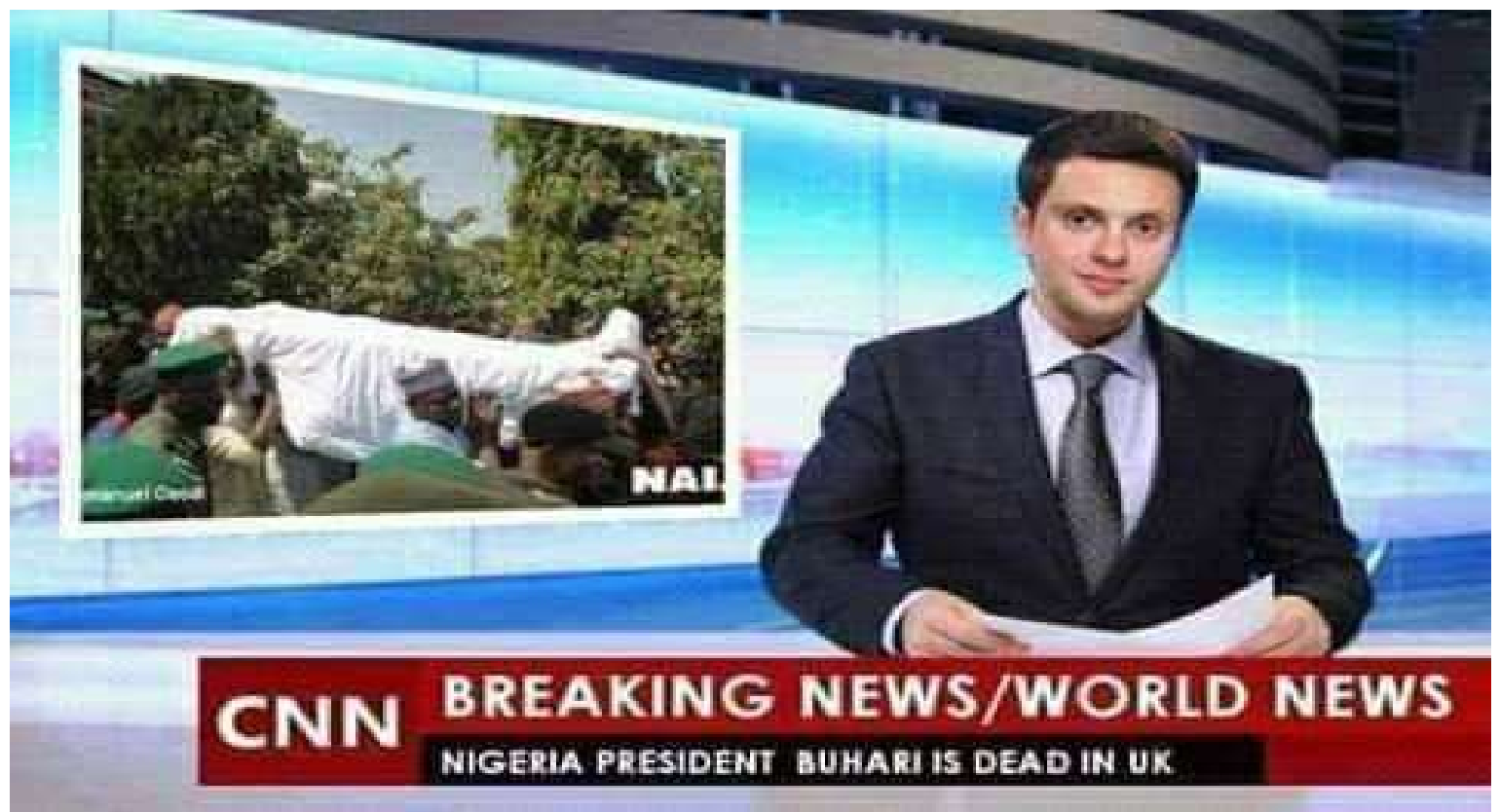

(FB: Biafra News; 9: 26PM; 15 November 15, 2018)

In the same vein, FP 7 is a fabricated news that was earlier published by Premium Times on September 11, 2012. It was reproduced with a change of date to legitimate fake claims that President Buhari's administration is incompetent, and thus does not deserve another term in the 2019 elections. Using the modified front page of Premium Times and attributing the news to Manufacturers Association of Nigeria, uncritical readers are persuaded to believe that 800 firms have shut down as a result of failed government's policies. In addition to using fictitious 'credible' media outfits, certain organisations such as the World Health Organisation are also used as experts in fake political health news.

Under role model authority, references are made to what famous or well-known people in Nigeria say or do. Such respected personalities are also always in the news, such as Prof. Wole Soyinka, Prof. Atahiru Jega, former President Olusegun Obasanjo, among others.

FP 9: "Buhari has finished fighting corruption, He should step aside, for Atiku to fight Poverty \& Hunger". Prof. Wole Soyinka (FB: CeleSylv Updates, 12: 02AM; 27 January, 2019)

FP 10: If the current INEC chairman can emulate me and conduct free and fair elections Nothing will stop Atiku Abubakar from winning 2019 Presidential elections" Prof Atahiru Jega (FB: Naija Must Work Again, 8: 52PM; January 23, 2019) 
Prof. Wole Soyinka is the first African to receive the Nobel Prize in Literature in 1986. People look up to him as a role model, not just because he is educated nor because he is a political activist, but because of the principles he upholds. FP 9 uses Prof Soyinka as an authority to convince readers of the authenticity of the claim that he supports the opposition party candidate who is campaigning to lift Nigerians above poverty against President Buhari who promises to fight corruption. In this instance, 'fake news' becomes a veritable tool by an opposition party to discredit other candidates by capitalizing on the unfulfilled campaign manifestos of their opponents as seen in FP 9. FP 10 also uses Prof Atahiru Jega as role model authority, knowing his impact as lecturer and former Vice Chancellor. He was reputed as corrupt-free, having conducted the 2015 elections where the incumbent President lost even though he was the one who appointed the INEC Chair, Prof Jega, at the time. The post therefore uses Prof Jega to legitimate the allegation that the ruling party plans to rig the 2019 election through the current electoral body. It is therefore a subtle allegation that the electoral body is corrupt and will rig the election in favour of the incumbent government. By attributing the news to Prof Atahiru Jega, the fabricator alleges that the election conducted by Prof Jega was free and fair since the incumbent president was defeated. It is also a deceptive campaign for the opposition party.

\section{Legitimation by Moralisation}

Moralisation legitimation involves making moral evaluations, abstractions and analogies to justify a particular action or viewpoint. In using this strategy, attempts to justify values or beliefs that indicate an action or practice as moral or immoral are initiated. For instance, words such as 'normal' or natural' are used to legitimate false claim that President Buhari is not fit for a reelection.

\section{FP 11: "BUHARI'S MEMORY LOSS IS NOT TOO BAD. - Keyamo.}

President Buhari's Loss of Memory is Normal, Even Jesus Christ and Prophet Mohammed Lost Their Memories At Some Point" - Festus Keyamo Reacting Buhari's Falling Memory and Gaffes.” (FB: Nigeria News; 6: 51PM; 6 February, 2019)

FP 12: Intelligence reports suggest that my friend and brother Nnamdi Kanu is being kept on a Nigerian naval warship far off the coast of Bayelsa and that Buhari intends to keep 
him there until 2019 and then drop him in the Atantic ocean after "winning" the February election... ...Know this: the incarceration, torture and murder of Nnamdi Kanu will not go unavenged or unpunished. The God of Justice will serve His judgement on all those involved in this sinister, gruesome and homicidal initiative. Buhari will soon know that God rules in the affairs of men. (TW; @realFFK; 6:39 PM; 2 July, 2018)

In FP 11, the word 'normal' is inserted in the speech of the spokesperson of the President Muhammadu Buhari campaign organisation to legitimate the news that President Buhari has falling memory and therefore is not fit for another term. In FP 12, which is a moral abstract, in which words such as 'incarceration', 'torture', 'murder', 'unavenged or unpunished', and phrases like 'God of Justice' and 'God rules' are used to appeal to the emotions of readers in order to justify the unlawful detention of the IPOB leader, Nnamdi Kanu, as immoral.

In addition, through moral analogies, the President's appointment is negatively validated as immoral.

FP 13: "Buhari appointed a Sharia court judge who was never called to bar or attended law school as Chief Justice of Nigeria...same way we elected the illiterate as President with no certificate Naija " (FB: Ibadan Mesi Ogo; 28 January, 2019)

In FP 13, using moral analogy, one negative activity (the appointment of an uncertified lawyer as Chief Justice) is used to justify another negative activity (the election of an uneducated President).

FB 14: “Alert! Alert!! Alert!!!: good day, please pass this message to everyone in Abakaliki and its environs. ... from $7 \mathrm{pm}$ every day, their gate should be well locked. The Fulanis now dress in Army outfits with dangerous weapons in their hands (with the) plans to come in and kill. If there is a knock on the gate from $7 \mathrm{pm}$ adult should attend to the person. Please don't open and don't talk. Let the person talk first. Tell your children also. May God protect us all. Sent as received" (WA: 00:25am)

FP 14 also takes a moral dimension in an attempt to give credence to fake news. This fake message connects with the happenings in the country such as the frequent reported attacks by herdsmen across the nation (Chiluwa and Chiluwa, 2020). The advice 'please don't open and don't talk' resonates with the warning given to children against opening the door for strangers or speaking to strangers. In addition to instilling fears in the readers, the post is intended to trigger political and ethnic hatred between the Igbo in the southeastern Nigerian (especially residents in Abakaliki city) and the Fulani in northern Nigeria. Such appeal to readers' emotion via moralisation acts as viable tool of justification in the fake news. 


\section{Legitimation by Rationalisation}

Theoretical rationalisation, describes the process of achieving an action by performing another action. In other words, the completion of one Action A justifies Action B. van Leeuwen (2008), puts it as ' $I$ achieve doing (or being, or having) y by $\mathrm{x}$-ing' or ' $\mathrm{x}$-ing serves to achieve being (or doing, or having) y.' 'For instance

\section{FP 15: Buhari has Finally Murdered Sambo Dasuki}

A reliable source informed me a few hours ago that Sambo Dasuki has been dead for a while but that Buhari and the inner circle insisted that news of his death must be concealed until after the election. "It's not the death and its concealment in themselves that are scandalous; it is how he died. Buhari instructed that he be denied his life-sustaining medications. That was precisely what killed him. "Buhari is an evil, vindictive, bloodthirsty monster. He will rig himself back to power and complete the annihilation of Nigeria that he has started well. I've done my bit to call attention to the evil fraud this man represents. It's up to Nigerians who live in Nigeria to either confront him or live with his evil. Good luck! I am done. (WA:

The accusation of Buhari of murdering Dasuki, first published on Twitter on the 22 February 2019 by Farooq Kperogi, a President Buhari's critic and Associate Professor of Journalism in the US. Kperogi took the post down the same day of posting. However, the post is continued to be shared on other social networks because it serves the purpose, and fulfils the intentions of the distributors, such as perhaps, instilling fear and hate in the readers as well as uses abusive language such as 'bloodthirsty monster' to refer to the President. Sambo Dasuki is a retired Nigerian Army Colonel and former National Security Adviser (NSA) to the former President of Nigeria, Goodluck Jonathan. He was arrested by the Nigeria's State Security Service (SSS) for allegedly stealing \$2.1 billion and has since been in detention despite being granted bail by four different High Court judges in Nigeria and ECOWAS Court. The post above rationalises fake information using meansoriented approach. Justification for a 'reasonable' action is provided to support another action. On the other hand, effect-oriented rationalisation is used to suggest certain actions that need to be taken. According to van Leeuwen (2008), it is represented by ' $\mathrm{x}$ has to do $\mathrm{y}$ so that/that way/because x can be accepted'.

Fake news also deploys theoretical rationalisation through definition. van Leeuwen (2008) suggests that definition occurs when one activity is defined in another moralised activity. For instance, the false story in FP 16 is intended to legitimate the possible false claim that the ruling 
party, APC whose main campaign manifesto is fight against corruption, also tolerates corrupt members.

FP 16:'Rotimi Chibuike Amaechi, minister of transportation and the Director-General of the APC presidential campaign organisation arrested by the police on Wednesday, January 23 on allegations of corruption'. (FB: AIT Nigeria News; 06:52 AM; 23 January 2019).

By definition, the action of the Director-General of a supposedly corrupt-free party is described as immoral. First the post tries to project the idea that APC's fight against corruption also extends to its principal members but, that also indicts the party for having corrupt persons occupying prominent positions in governance, such as the Minister of Transport. Two activities underlie this - arrest of the Director-General and allegations of corruption. The first is dependent on the second.

\section{FP 17: OLUSEGUN OBASANJO CRIES FOR FORGIVENESS -}

My Worst Mistake Was Electing BUHARI As A President, Nigerians Should Forgive me - Obasanjo Apologized To Nigerians. I am asking for his forgiveness for the reasons I've carefully itemized below. (WA: 00:25am; 18 February, 2019.)

FB 17 which was shared as 'forwarded' on a WhatsApp group platform presents the following information - first is the election of the President by the former President, Obasanjo, next is asking for forgiveness. The first activity which is portrayed as a mistake is dependent on the second hinged on a contrite change of heart. Through linguistic items such as 'cries', 'apologised', 'forgive' and 'worst mistake', the fake post constructs the seriousness of the situation as well as persuades the reader to agree with the contents. This strategy is coercive considering the strong military and political background of the supposed writer, Ex-President Obasanjo. Thus, FP 17 combines personal authority (i.e. President Obasanjo) and rationalisation to disinform the readers

\section{Conclusion}

The study has examined the recurrent legitimation strategies used by Nigerian fake news creators in justifying their posts. Findings reveal that through expert and role model authorisation, appeal to emotion, using moralisation and rationalisation, texts creators are able to subtly pass their messages across to their readers as well as attempt to validate their disinformation. The strategies are viable persuasive tools owing to their use of discourse markers like make-believe images, emotive language, appeal to emotions, rational conclusions, hateful comments, verbal indictment 
and coercive verbs. From the analysis, it is clear, in line with Ahmad, Alvi and Ittefaq, (2019) that political influencers rely on fake news to either rundown their opponents and engage netizens in political activities. The study identifies that mythopoesis is rare among Nigerian fake news creators probably because of the need to be concise with fake news details.

\section{References}

Abdulrauf, A. A. (2016). Cognitive engagement and online political participation on Facebook and Twitter among youths in Nigeria and Malaysia (Doctoral thesis). Universiti Utara Malaysia, Changlun.

Ahmad, T. Alvi, A. and Ittefaq, M. (2019). The Use of Social Media on Political Participation Among University Students: An Analysis of Survey Results From Rural Pakistan. Sage Open. 9 (3): $1-9$.

Albright, J. (2017). Welcome to the era of fake news. Media and Communication, 5(2), 87 - 89.

Allcott, H. \& Gentzkow, M. (2017). Social media and fake news in the 2016 election. Journal of Economic Perspectives. 31 (2): 211 - 236.

Amobi, I. T. (2019). From reducing fake newsto validating the facts:A triangulated evaluation of the awareness and impact of Africa Check's work in Nigeria in www.africacheck.org

Aririguzoh, S.A.

TheArt of Deception in Political Advertising: A Study of Nigeria's 2015 Presidential Ele ction Campaigns. I.E. Chiluwa and S.A. Samoilenko (Eds). Deception, Fake News and Misinformation Online, 349 - 374.

Assay, B.A. (2019). Social media and the challenges of curtailing the spread of fake news in Nigeria. I.E. Chiluwa and S.A. Samoilenko (Eds). Deception, Fake News and Misinformation Online, 226-263.

Bovet, A. \& Makse, H. (2019). Influence of fake news in Twitter during the 2016 US presidential election. Nature Communications. 10(7): 1 - 14.

Chiluwa, I.E., Ovia, E. \& Uba, E. (2019). “Attention beneficiary...!": Assessing types and features of scam emails. I.E. Chiluwa and S.A. Samoilenko (Eds). Deception, Fake News and Misinformation Online, $421-438$. 
Chiluwa, I.E. \& Chiluwa, I.M. (2020). 'Deadlier than Boko Haram': Representations of the Nigerian herder-farmer conflict in the local and foreign press. Media, War \& Conflict, Sage Journals.

Chimuanya, L., \& Ajiboye, E. (2016). Socio-Semiotics of Humour in Ebola Awareness Discourse on Facebook. In Analyzing Language and Humour in Online Communication, R. Taiwo, A. Odebunmi and A. Adetunji (eds). Pennsylvania: IGI-GLOBAL, 252 - 273.

Jun, Y., Meng, R. \& Johar, G. (2017). Perceived social presence reduces fact-checking. Proceedings of the National Academy of Sciences. 114 (23): 5976 - 5981.

Kellner, D. \& Bohman, S. (2013). New Media and Social Movements. Journal of Political Sociology, 10 (15): $20-30$.

Lazer, D. M. J., Baum, M. A., Benkler, Y., Berinsky, A. J., Greenhill, K. M., Menczer, F., Metzger, M. J., Nyhan, B., Pennycook, G., Rothschild, D., Schudson, M., Sloman, S. A., Sunstein, C. R., Thorson, E. A., Watts, D. J., \& Zittrain, J. L. (2018). The science of fake news: Addressing fake news requires a multidisciplinary effort. Science, 359(6380), $1094-1096$.

Nababa, G. S. (2016). Information credibility on social networking sites: a study of a salt-andwarm-water anti-Ebola prank in Nigeria. WIT Transactions on Ecology and The Environment, 203: 245 - 255.

Okafor, J. (2018). The mis(information) you choose to believe could be harmful. Retrieved from http://www.dailytrust.com.ng/the-misinformation-you-choose-to-believe-could-beharmful (accessed 20 October 2018)

Olabamiji, O.M. (2014). Use and misuse of the new media for political communication in Nigeria's 4th Republic. Developing Country Studies, 4 (2): 44 - 53.

Parkinson, J. (2018). Nigeria gripped by whether President is a clone. "It's the Real me, I assure you',. The Wall Street Journal, December, 10, 2018. 11: 35am ET https://www.wsj.com/articles/on-the-issue-of-whether-ive-been-cloned-an-election-gets-weird1544459732

Prasetyo, R. \& Asiyah, U. (2017). Social Media, Radicalism, Terrorism and Threats for Democracy Process in Public Space. In Proceedings of the International Post-Graduate Conference on Media and Communication (IPCOMC 2017) - Media and Communication in the Politics, Industrialization, and Empowerment, 401 - 404. Date: November 13, 2017. Venue: Harris Hotel and Convention, Surabaya, Indonesia

Robinson, S. \& DeShano, C. (2011). 'Anyone can know': Citizen journalism and the interpretive community of the mainstream press. Journalism. 12. $963-982$.

Rojo, L, \& van Dijk, TA (1997) There was a problem, and it was solved! Legitimating the expulsion of 'illegal' immigrants in Spanish parliamentary discourse. Discourse \& Society 8(4): 523 - 567. 
Silverman, C. (2016). This Analysis Shows How Viral Fake News Election News Outperformed RealNews on Facebook. BuzzFeed News, November 16.

Social media statistics (https://www.socialpilot.co/blog/social-media-statistics

Social Media Poll Report (November, 2019) Nigeria's Teledensity and Preferred Internet Access Device. www.noi-polls.com

Stieglitz, S. \& Dang-Xuan, L. (2014). Social Media and Political Communication - A Social Media Analytics Framework. Social Network Analysis and Mining. 3. 1277 - 1291.

Tandoc, E. C. J., Lim, Z. W., \& Ling, R. (2018). Defining "fake news". Digital Journalism, 6(2), $137-153$.

The Guardian (3 December 2018). 'It's the real me': Nigerian president denies dying and being replaced by clone. Available at: https://www.theguardian.com/world/2018/dec/03/itsreal-me-nigerian-president-denies-dying-and-being-replaced-by-clone

Uzochukwu, C. E. \& Ekwugha, U. P. (2014). New media and youth's online civic engagement in Nigerian politics: Potentials and challenges. European Scientific Journal, 10(19), 203 221.

van Dijk, Teun A. (1998d) Ideology: A Multidisciplinary Study. London, Sage

van Duyn, E. \& Collier, J. (2019). Priming and Fake News: The Effects of Elite Discourse on Evaluations of News Media. Mass Communication and Society. 22 (1): 29 - 48.

van Leeuwen T. \& Wodak R. (1999) Legitimizing immigration control: A discourse-historical analysis. Discourse Studies 1(1): 83 - 118.

van Leeuwen T (2007) Legitimation in discourse and communication. Discourse \& Communication 1(1): $91-112$.

van Leeuwen, T. (2008). Discourse and practice: new tools for critical discourse analysis. New York: Oxford University Press

Vosoughi, S. Roy, D. \& Aral, S. (2018). The spread of true and false news online. Science. 359: $1146-1151$.

Wardle, C. (Feb 16, 2017) Fake News. It's Complicated, First Draft, https://firstdraftnews.com/fake-news-complicated

Kazeem, Y. (2019). WhatsApp is the medium of choice for older Nigerians spreading fake news. Quartz Africa Report, 22 October, 2019. https://qz.com/africa/1688521/whatsappincreases-the-spread-of-fake-news-among-older-nigerians/ 